\title{
CHARISMATIC LEADERSHIP
}

\author{
MusMulyadi \\ Harsallakum Al-Quran Islamic Boarding School \\ Mmus3684@Gmail.Com
}

\begin{abstract}
Charismatic leadership involves determination, authority, openness, and the optimism of the leaders in Bengkulu City HarsallakumPesantern (Pesantren = Islamic Boarding School). This research uses descriptive method, as well as qualitative case study. The processing of data is done by data reduction, serving of the next, as well as doing the valid checking using triangulation technic, followed by concluding the findings. The result of the research, has swon that the leadership of Pesantren leaders has been a model for the people around. Being an example or a role model has created a harmonic relationship between Santri (cultural 'stream' of people within the population of Javanese who practice a more orthodox version of Islam) with the Usthad (Islamic leader). The prestige of the Pesantren leaders has created an awareness for their subordinates, that to accept, prestige has to rise from the bottom going upwards. The openness of the Pesantren leaders acts truthfully, humble, just, as well as open in accepting opinions and critics from others. The openness of Pesantren leader shows the clearliness in taking decisions, planning process that gives a chance to all subordinates. Optimism of the Pesantren leaders are behaviors that is born or created inside of the leaders in perceiving their problem, facing hardship, and thinking optimistic. So that the biggest strength is giving enery and directions in reaching the destination.
\end{abstract}

Keywords: Charismatic, Leadership, and Islamic Boarding School

The pattern of leadership in Pesantren is very much influenced by the leadership of a Kiai(expert in Islam) or leaders in the Pesantren itself. In the future development, personal leadership and personal are started to be realized by the Pesantren leaders that it cannot be hold off fully, the Kiai/Usthad started to adopt the modern leadership style. Because of it, the leadership of the Pesantren leaders is a spirit and elements of Pesantren that cannot be separated. The Kiai or Pesanren leaders, besides an opinion leader are also starting to reach the symptoms of social changes that is needed. The personal profile of the Pesantren leaders really set the movement quality and the pesantren activity, until the color of the pesantren is identic to its leaders.

The sustainability and the continuation of the pesantren as the main base is the standard of the leaders, in which the Kiai in this matter has the vision and the high charismatic. Pesantren that has this kind of leaderhip will decided their own sustainability, because it cannot be denied that the leader's charismatic are the soul of the Pesantren. Many findings shows the regression in the Pesantren's growth when the Kyai has no vision or when the Kiai depart from the place. Because the leaders of the Pesantren should have a strategy to influence their subordinates for the Pesantren's importance, that the existence of Pesantren still have a high bargaining competition in the community.

Gary Yukl (1994:21) stated that the leadership is like a process in a group to reach the destination together. Leadership is of the individual, directing the activities of a group that shares a common goal. Davild Wilkins (1976:25) stated that leadership is frequently used, and only few executives in business today can be considered true leaders. Whereas Gold(1998:26) stated that leadership is the process of guiding followers in a certain direction in the pursuit of a vision, mission, or goals; making and implementing and evaluating policy.NgalimPurwanto (2006:26) defined leadership as 
a batch of a series of ability and personal attitudes, with prestige in it, to be made as a means in convincing those being lead so that they want and are able to execute the tasks that has been given with sincerity, willingness, full of energy, and with personal happiness. One of the type of leadership is charismatic leadership. Max Weber in Yuks (2005:290) stated that charismatic is a word in Greek language that means "blessings that are inspired gloriously" like the ability for miracles or predicting the future events.

While Jandaghi (2009:359) explained that Charismatic leadership is a component of transformational leadership and idealized influence icludes idealized traints and idealized behavior. Inspiring the honor and proud to follwers and their contribution to group intersnts are, inter alia, most obvious idelizedchariacteristics of a leadr. Followersexltation, dignity, respect and unquestioned obedience transmit an idelized feeling. Talking about the most informatant values and strong feeling to aims as well as spritualand moral result of decisions are among idelizedbehivior indicators. Idealized influence causes that leadr be a behavuoral model for followers. Yulk (2010:263) added that Charisma is a greek word that mean divinely inspirid gift, such as the ability to perform mirales or predict future event. Used the term to describe a from of influence based not on tradition or formal aauthority but rather on follower perseptions that the leader is endowed with exeptionalqualities.From the explanation above it is clear that the characteristic and behavior of charismatic leading involves: 1) Determination. 2) Prestige/Authority. 3) Openness. 4) Optimism.

The leaders' behavior of determination are by showing to their subordinates regarding on what they should do, giving exampes and be involved in an symbolic actions that tells the members what is expected of them, as well as telling the proper behavior to be done. This determination can be shown in time discipline, obeying the rules, procedure, tasks and responsibility as well as actions. Referring to Kouzes' (1999:288) opinion, which leaders that are asking other to change, as what Cochran did, is not enough to just give a speech that energizes the spirit. While strong and building words might be very important to elevate other's sould.Covhran and its leaders knows that the movement of the participants works deeper than actions.

NgalimPurwanto (1999:48) stated that Prestige or Gezag (derived from the word Zeggen that means 'to say'). Those whose words have bonding power over others, means have prestige or gezag over other. Muhammad Surya )2013:328) expressed prestige as an element of personality on a person as personal or as a holder of a certain authority. Publicly, prestige can be defined as a personal quality on a person that makes other be attracted, trusting, respect, and intrinsically appreciating, as well as following them intrinsically. The advantages, and virtue of the leader so that they can manage others and be obedient to them.Prestige are a part of something inseparable from a leader. Robins (2005:119) explained that many suspicion arise from what is not known not from what people knows. Openness results in beliefs and trust. Try that people will gain information, try that the criteria regarding the decision making process is stated clearely, and is explained why the decision is made, be frank about problems, and fully deliver the relevant information. Shelthon (2009:101) says that be an open person, curious, and ask a lot as well as recognize that people in the front line also have inputs and opinions that are valuable. Show recognition and appreciation on those ideas stated. Because of that, FakryGafar in DewiDeswary (2014:242) explained that leadership capacity requires 5 approaches to be firm and effective to be a leader especially in the field of education, which is rich professionalism, empowerment, participation, transparency, and accountability.

Charismatic leadership can be shown with the openness behavior of the leader in managing the organization. Zalezned (2008:14) stated that "Eisenhower led the way in meeting with chuchill in convincing the british. Eisehower's optimism, goodwill, and the absence of ego proved convincing." According to Gene Kalann (9), "If you learn to conduct yourself in a certain manner, your behavior will 
reflect a cartainqulaity such as courge, caring, self control, optimism, and ready communication. None of these attributes is innate and all five of them lie at the hert of afective leadership." As Suwaidan (117) also says that a leader should have a confident attitude which is the belief that leaders in his expertise and potential will reach the goal and act in a way that makes the follower trust in his abilitites.

Pesantren is derived from the word funduq (Arab) which means a sleeping place or a humble home, because it is a place of shelter for students that live in a far away place. Muthahar (2015:11) explained that the etimology of the word Pesanren s from the word "satri" which when being put into Pesantren means a place of stay for santri. Poerwadarminta in AbudinNata (2013:314) explained, that the word pesantren comes from the word pesantrian, which means dorm and place for students to learn how to Koran or mengaji - reading and understanding the meaning of Al-Quran. Putra Daulay (2014:1) says that the word pesantren is from the word cantri which is taken from Tamil language which means the teacher of Koran.As a religious institution,pesantren holds the role that is strategic. Amir Faisal (1995:183) explained that pesantren education launch its objectives as the following: (1) print clerics that controls religious study, this group oversees the people that gives warning and education to its people to act and think, as well as work in accordance to what the religion has taught them, (2) to educate Muslims that can execute the religion Shari'a, (3) to educate so that the object have basic skills that is relevant with the forming of a religion community.

Munthohar (2008:19) stated that the purpose of pesantren is not only creating an intelligent human intellectually, but also creating a faithful, ethic, esthetic, Godly, as well as keeping up with the development of the community so that they can become a complete human and is useful for the community. To establish pesantren, some aspects like the dorms, mosque, santri, kiai, and the yellow book teaching (pengajarankitabkuning) should be fulfilled. The methods that's proper to be used in pesantren involves the Sorogan, Wetonan, Ceramah, Muhawarah, Mudzakarah, MajelisTa'lim, and Kombinasimethod.The development of pesantren should also be developed so that pesantren can be equal with other school or educational institutions. What can be done by the pesantren in the development are the development of human resources that is important to watch over and increase productivity. Another effort that can be done by pesantren is education and doing training. Robbins (2002:317)explained that when the work demand changes, the expertise of the employee should be changed and renewed, managers are required to hold responsibility in deciding the type of training that the employee needed, when they need it, and which form of training will be taken.

\section{METHOD}

This research tries to review deeply about the charismatic leadership in Bengkulu city HarsallakumAlquran Islamic Boarding School, then the type of research used are the descriptive type. As to what Arikunto's opinion has stated (2014:3), a descriptive assessment is an assessment that tries to picture and interpret phenomenon that is currently happening in the field. While the approach uses in this research is through case study. Data analysis done is collected and afterwards will be process with content analysis which puts the fact analysis and natural findings in the field first. In the research of this research, each process of data analysis is as the following. (1) Data analysis when the researcher is at the field, (2) Analysis post data collections that involves (a) data reduction, (b) data display, and (c) Conclusion.

As the leadership of the Usthad in Harsallakumpesantren has given an example for those around them whether inside or outside of the pesantren. Accordingly, HariusRusli so that every actions, and expression can be meaningful should be done willingly without expecting anything in return from anyone. It includes leadership, if tasks and responsibility are done willingly then whatever is done will be good and beneficial for the personal self, others, even the institution that is being lead.According to the 
leaders in Harsallakumpesantren, every words uttered by the leaders to their subordinates that are not always meaningful is the people that can understand the situation and condition around them including the subordinates (not all words uttered by the leaders are rules, command, instructions, request, etc. that should be done immediately. What matters is how the leaders can guide the subordinates to act according to their priority scale. Which means that the subordinates should be guided to do jobs in accordance to their priority scale).The effect of the determination is the people being guided feels sure about what is being done and commanded by the leaders are true and suitable to be followed, they agree to obey the leaders, they care for the leaders, and emotionally involved in the group or organization's mission, and they choose to have high performance target and they are sure that they can contribute to the success of the mission.

According to the rules of pesantren leaders that determination is the impression that arises personally from others that are around us. So the presence of determination will arise when we have done something or do a certain activity. We will not show and/or give determination to our subordinates if we haven't done or do something in the community of the people being lead. The meaning of determination will arise after the completion of a good activity as a leader or personal. For me, what is being done in leading the Harsallakumpesantren is not based on what the public will see, praised, or get an award but purely based by my calling to teach young generations by building pesantren. In my daily activities, I did not ask or command them to make me as their exemplar, but if there is any positive and beneficial behavior it is free for them to take example from it.

In the view of pesantren leaders, determination will ease the teachers in doing an evaluation with the outcome of the learning and teaching process and easing the santri in practicing and implementing the knowledge learned throughout the education process. Determination can create a harmonic relationship with the santri and usthad. With determination, the goal of education that wanted to be reached will be more direct and reached better and with the determination of the usthad or the teachers that indirectly implement the knowledge that they're teaching. What's important is that determination also pushes the leaders to eternally do good because the personal realization will be emulated by their subordinates.

The relation with openness is really tight in terms of relationship, the general purpose of Islam education is to lead the child to be a true Muslim, have a firm faith, godly, and have a noble morals that is useful for the community, religion, and the nation. Effort is needed to reach such goals, education is a form of the effort while methods are a way to ease the process in reaching the goal/destination. In this matter, determination plays an important role as a method in reaching the goal of Islam education.

The pesantren leaders have a view that the life of a human is not far from other humans. The behavior that exists in a human tends to have the same unity, this can be found that a person do something because they are obsessed with what others have done. It is also common that the behaviors that exists in humans have a tendency to copy from others. If observed historically the education during the er of Rasulullah SAW, it can be understood that one of the main factors that brings him to success is determination.

Even determination have a relationship with the outcome that the teachers and other subordinates that view that every job that can be done productively, halah, and not disobeying the law should be appreciated and seen as a source of income and blessings. Because of that, it is always emphasized to the subordinates to appreciate the job being done and make it their responsibility.

Other than that, the job being done is a chance for the subordinates to develop themselves and devote. Through their work experience, the teachers and other employee in Harsallakumpesantren is given the chance to develop their potential and personal ability until it can be beneficial for a good personal life, family, even the community. What is emphasized to the subordinates is that a job should 
not be put to waste because it will be a disadvantage if the chance to work is wasted. With viewing work as a chance, then all subordinates will do their job joyfully and earnestly even without supervision.

The Usthad as pesantren leaders are full of confidence in motivating their subordinates. The leader/Usthad always try to notice and consider their ability and potential. Besides that, what matters to be noticed the most is the needs in executing their job so that every tasks done will go smoothly and can be finished as well as possible.The explanation above pictures that the leaders/usthad have a principle that everything done should be done willingly. Giving orders to subordinates should be followed by giving the subordinates' freedom to determine their own priority scale measures on what needs to be done.

The success of a leader besides being determined by their attitudes and behavior, is also determined by their prestige. Prestige as one of the leadership concept involves all aspect related with the leadership of a person or a group of people to influence others. One of the main point that should be noticed by the teachers is how they keep the discipline in doing their tasks and responsibility as a teacher. This is because the influence of discipline is very exceptional for the success of their job. From here is where the pesantren builds the quality of their teachers. Besides that, to increase the career and their knowledge, it is also given chance to them to join career enhancement programs like teacher certification, the opportunity to continue their stud and undergo training, seminars, workshops, etc. that of course is beneficial to the teachers personally.

According to the pesantren leaders, the elders of this pesantren institution that shows prestige will increase the awareness of the subordinates to accept his prestige, because it is felt right and kind, so that the subordinates feel as one with their superiors. So, the personal prestige arises from the bottom to the up, because there arises a willingness from the subordinates to follow and do what their superior wants.

Prestige has a role as a pusher for every leader, because in influencing, moving, and changing the behaviors of the subordinates to the direction of the goal besides the various leadership technic needs some certain force that is called prestige."Prestige in leadership does not mean constant respect, obedience, or feared because prestige is not merely to make people that is being lead feel pressured. Prestige does not mean that the leaders should be smug, but to act to keep the consistency and the harmony between words, actions, and behaviors to the subordinates."

The most important part in leading is actually the invitation to do the best without prioritizing command, even pressure to the pesantren people. Because if people follows what is wanted by the leaders because they did not feel like they are being commanded to, but because of the invitation shown by the leaders through his actions and words, it actually is what is meant by prestige. In other words, prestge is not a personal subjective evaluation, but it is the evaluation of other people that accept the presence of a leader.Tasks and responsibility in leading a pesantren will feel heavy if done with only just putting forward the order/command, pressure or force to those being lead especially the teachers, employees, and the santri. Because of that, the Usthad do their job involving others through his actions and words. Without realizing, this matter makes the teachers, employees, and santri do their job without being forced and commanded and are willing and able to do their tasks and responsibility to increase the quality of education in HarsallakumPesantren.To conclude, it is prestige that is the effort in moving the subordinates in reaching the goals that has been set. A leader have a good situation if whatever he supports is the prestige of a job and personal prestige.

The openness of a leader will create a trust behavior with the leaders and those he lead. The trust is crucial in maintaining the continuity of a institution or organization like this pesantren, because this pesatren stands based on the beliefs and attitudes of keeping each other's trust between the founder and 
all parties involved in the building of pesantren. The openness that is being put upfront in Harsallakumpesantren is honesty, humbleness, just, as well as accepting opinions and critics from others. It is related with the execution of the education in the pesantren, nothing is being covered up to all parties and anyone can freely express their opinion and deliver their aspiration. If that opinion can be accepted and is building, it can be put into consideration and be used to be better and best.

Openness leadership shows the clarity in taking decisions, the planning process that gives a chance to all subordinates in expressing their opinion and if ever the opinion of the subordinates are rejected, it will be equipped with the reason why it was rejected.Openness should exists in every Muslims so that they can be able to face temptations and challenges with hardwork and endeavor. For that, it should be observed among the strengthening of faith to Allah SWT, avoid laziness, do not give up easily, pray to Allah so He will give strength to always endeavor, keen, and enthusiastic in doing any effort, persistent in doing work, uses time wisely, hopeful, always try to advance his/her effort, put their trust in God as an order that found many times in Al-Qur'an, besides other command like fear of God, patient, sincere in worshipping, act justly, etc.

Optimism is one of the biggest strength for humans. Optimism gives energy and destination to the end goal that is created before the real life action. The brilliant orators and many big time writers have changed the world with their ability to communicate what they have. It happened because they have think optimistically many many days before he/she is known by people. When he/she started to rise in the career, there are many challenges that they should face. He/she keeps on waling on the path that they have chosen. What people know is only a small part of his/her success, while hundreds even thousands of his/her unsuccessfulness are ignored. That is the result of optimistic thinking. Every optimistic ac can be brought upon anywhere, even in suffering situation.

Pesantren leaders view optimism as a behavior that burns inside an individual that is a behavior according to the problems that they are currently facing. The behavior towards something constitute of an evaluation whether it's negative or positive. Optimism behavior are a choice tht arises in a person in perceiving his or her trouble. Optimism are the opposite with pessimism that orients around negative behavior. Many life pressures a person has to endure makes them feel frustration. Some people have to feel the burden or stress of their job because the burden is too big for them. Other problems like natural disaster and death of a closed ones can also make depression and frustration. Only little of the population are able to avoid daily life pressure that can create frustration and pessimistic point of view. Even though facing sufferings and life pressure, thinking optimistically are beneficial especially for the health.The importance of optimism in leading to resolve problems and increase condition to be better to reach a solution instead of analyzing issues related with the problem. Approached based on solution that is being used while leading will increase creativity and innovative thinking. Optimistic behavior will makes us used to thinking outside of the common thought other people have.

Nowadays, according to the view of the leaders in the pesantren, all things can change very quickly. Those changes can hold off someone in developing. Moreover the leaders, which the position is crucial for an organization and also be an example for its members. If the leaders did not grow well, then the continuity of the organization will be affected. Because of that, it is important for a leader to have an optimistic behavior and think positively. In having those behaviors, the leaders will be able to adjust themselves with the current development. A leader that is optimistic and think positively will always have a future oriented thoughts, not afraid of failure, always able to motivate their members that are slumped, and an optimistic leader that think positively can transmit their behavior to the people around them.Optimistic behavior and positive thinking will make people immune with slump because of failure. The prolonged slumped will affect the result from an organization. Whereas if the one that's feeling the slump are the leader that is the role model for its member. It will create chaos in the organization. 
According to the pesantren leaders, optimism is a strong power of human. Optimis gives energy and direction to the destination that has been created before the real life actions. The brilliant orators and big time writers have changed the world in their ability to communicate with what they have. It happens because they have think optimistically days far before people know them. When he/she started to rise in the career, there are many challenges that they should face. He/she keeps on waling on the path that they have chosen. What people know is only a small part of his/her success, while hundreds even thousands of his/her unsuccessfulness are ignored. That is the result of optimistic thinking.

Optimism (in Islam it is almost equivalent with the word husnodzan), thinking positively or positive thinking is a formula, or a paradigm, a thought structure. A systematic thinking system.Viewing something from its positive side only, despite other people viewing it as bad. Optimistic people usually can reach what they wanted compared to the pessimistic, which is the people who view something from the negative side. Pessimist people have failed, even before staring something. Optimistic people have succeeded, before even he or she do her job. Something unexpected will be uncovered, that during the course of the like of the pessimistic people, there is no hope in going forward. No hope in living happily. Many people are trapped in their own paradigm. Paradigm that is far from the universe's reality.This method that is done to be optimistic is always thinking positively because this is something important that remembers that leading is what people perceived as role modeling. But before the leader have such behavior, there are some aspects that should be notice if the leaders wants to possess such behavior.

Charismatic leader are identic with a person's religion experience, that is why charismatic leader usually shows up or born from groups of people that is smart with their religion. This matters are related with morality as it is the based shown from the religion's values. The moral itself is what can influence people so that people will sympathized highly to them. The charisma of the pesantren leader (usthad) are of course an exceptional energy in a sense of giving power to create an influence in the pesanren area as well as outside of the pesantren area.

The born of a leader in pesanten (usthad) are usually based by the physical conditions of someone who have a body that is big, tall, or an orator even through hereditary that has a high charisma. Another factor is the competency that someone have where the expertise in a certain aspect like for example in religion, as well as the ethics and the behavior in practicing the values of the religion with their ability in the attitudes shown to control themselves in the community.

The pesantren is a unique religious institutions where the Usthad and the pesantren is like the two sides of a currency where one is related with each other. The institution of the Pesantren nowadays have experienced changes Harsallakumpesantren under the leadership of H. HarusRusli, Lc, as the pesantren shelter that always give guidance for 24 hourse, where the pesantren also always creating an amotsphere that is not boring for the santri, when the santri is being served and educated like a family. The Usthad of the pesantren is a model that set the growth of the satri, where the liefe of the Usthad that is shown in a strong personality gives an example that is good, competent in religious study, is a factor that becomes the consideration of people to entrust their child to pursue their education. This kind of behavior for a teacher gives inspiration as well as motivation in doing their job. To create the spirit of orking of the teachers, Rahayu (2015:94) explained that principals/madrasah always helps the teacher in various types of problems, care for their subordinates, giving motivation o that the teachers can work in their maximum effort, while being an example, as well as giving rewards.

Dale Carnegie (2015:20) stated that they lead by giving examples as well as act with full integrity in their personal and professional life. Whether in undergoing their own opinions or others, they work to make sure what has been planned will be reached.Usthad are a figure for the santri, where the usthad that have advantages in forms of charisma. Not only that, the usthad of the pesantren is like the second parents after the person's own parents in their home. The Usthad in pesantren is a role model that 
can be imitated all the times by the santri, and because of that the situation of the pesantren influenced the satris to always follow that is done and do by the Usthad in the pesantren. Not only the santri have a strong beliefs thathteUsthad is the Wasilah (etymology) in forms of preparating the Islamic generation, which is the warasatulambiya.

The usthad in the pesantren is an elemt of the pesantren that is very important, because of the usthad as a role model for the santris. The usthad are a figure that is imitated/be as an exemplar as well as making himself a parent. Because of that, the climate of the pesantren is always created by the usthad to involves themselves in giving guidance to the santri, because the usthat are a source of a strong pushing energy in realizing the behavior of santri to be in accordance with the hopes and the goa of the pesantren. It would be really lovely if the satri can identify models from many sources.

Prestige, the life of someone after being born is a condition and a process of organizing that's heavy at work so that it can create mature attitude and behavior. The growth factor of a person cannot be separated on how he or she observes and feel what is happening inside them. Because of that, the people around the child are able to contribute into the growth and development of the child. One of the factors around them is the teachers, and the adults that frequently interacts with the child.Thepesantren as an educational institution have a main tasks in leading the santri to be an adult. It is realized by the people who entrust their child in pesantren with a living place without parents.

The guiding method of the pesantred, kyai, usthad, and other mentor in an adequate amount, can replace the role of parents while the child lives in the dorm. Kyai and Usthad in the pesantredacts in 2 matters for the santri, which is as a role model and a therapist.To fully influenced and move such thing, a leader needs prestige. Even it can be said that leadership is nothing without prestige. It can be said that leadership is nothing if not equipped with prestige. Dimyati (2015:69) stated that the success of leaders is viewed from the source and the happening of some prestige that exists in the leaders, and how the leaders use those prestige to their subordinates. Next, leaders that have prestige is a leader that assume that their member are always with them to build the organization. Leaders assume that all of his members are his brothers. Leaders acts as a caretaker, as a parents for all members. Leaders like this is a leaders that is idolized all the time. Marhawati (2016:20) stated that the success of a leader is shown with his ability in executing his leadership taks in influencing all the school resources. Prestige really affect in the school reaching its target/mission.As part of a prestige leading, the leaders of the pesantren have shown the attitudes as a leader that can be imitated and followed, even though the residence of the Usthad is not in the pesantren area.

Openness arethe ability to listen to new ideas even though the ideas presented is not in accordance as what the leaders have hoped. Openness will build respect and trust with regard of new ideas that are beneficial to realized the vision. Ken Shelton (2002:101) suggested, be an open person, curious, and ask questions as well as acknowledge that people in the frontline have inputs and precious ideas as well. Show recognition and appreciation on those ideas.

\section{DISCUSSION}

The openness of a charismatic leader will imply to the development of an effective leadership through means like the following (1) communicate clearly and routinely. Explain in details the purpose, mission statement, and mission implementation that should be done. (2) involves subordinates in setting the destination or the purpose (3) give authority to the subordinates and buid their responsibility. (4) be responsible for your own as an effect of the policy that is taken. (5) be trustworthy and expand trust to subordinates. This will help the leaders in getting the subordinates' loyalty.

The leadership in Pesantrenhave reached many stages that affect the leadership which is the first step in the vision statement of the leader. Vision is a long term strategy to reach the destination or a 
series of destination. The vision that is brought upon by the charismatic leaders give a continuity nuance for the follower where he tries to connect current conditions with the future that is better organized. Zubaedi (2011:171) explained that aligned with the principles of modern leadership, where every leader should have visions, where a leader is a learning human, have big ideas that are visionary, and be a main reference for those he leads. On second phase, after the vision and mission has been set by the leader, they will later communicate the expected high performance with beliefs that the followers are able to reach the visions that has been expressed. The effect of this beliefs makes the follower more confident.

The term openness or with other terms called transparency in the context of pesantren leadership is very clear which is the conditions are as what it is, not being lied to, honest and open to the public regarding whatever that is being done by the learning institution. The data that is reported by the pesantren leadership mirrors the true reality and in instance to all related parties or stakeholders.

In this relation, as learders of the Harsallakumpesantren has tried to increase the transparency of the school to the public through (1) the usage of many good communication means whether directly and indirectly through print media or electronic means. (2) Creating a rule that guarantees the public rights to get information of the pesantren, the facility database and the information and communication means.EvenHimam (2014:214) stated that the openness at the end will create a horizontal accountability between the leaders with the pesantren members so that the pesantren will create an efficient, effective, accountable, and responsive educational institution to the aspiration and importance of the pesantren members like the teachers, santri, parents, and even the community. Openness gives a contribution to the increase in employee performance.

Optimism, Leader communicate his or her expectations, which one of it are optimistic behavior. With the optimistic view will give a strong influence towards the subordinates and other around. To obtain that optimism, a leader can't get it freely like through his dream, but the optimism should be obtained through deep thinking and correct analysis so a correct prediction will be created. In that sense, it can only be done by those who have wide knowledge. A person without knowledge will find it hard for them to start something, especially if they have to lead and organized an organization.

Besides high optimism, leaders should also be able to convince his or her members that the prediction that is born from his or her deep thought will not miss and will need the help of the brothers fighting the same fight with him. One stick will not be of use without the other stick, so that to reach a destination, a person should not walk alone, but he needs other hands to hold, strengthen each other and complete one another, remembering that each human have a unique potential to be diverse and have soft skills in opposite fields.

But in overly acting optimistically will bring a person into pride and will lead him to the pitfall of destruction. With that, we should be optimistic by balancing it with hardwork as well as relying ourselves to Allah SWT. If a person only acts optimistically without being followed by real actions and hardwork towards the goal will not be reached. Following are 8 reasons why optimistic people can lead better (1) optimistic people usually focus on the resolving of a problem, (2) optimistic people are not afraid of failure, (3) optimistic people are abll to communicate well, (4) optimistic people are future oriented thinker, (5) optimistic people always collaborate, (6) the behavior of optimistic people are contagious (in a good way), (7) optimistic people always motivate, and (8), optimistic people have a success way of thinking.Optimistic leaders will not protract during hardships. They push to understand the current conditions, planning the future, an taking actions as well as doing so.

\section{CONCLUSION}

The general conclusion of charismatic leadership in Bengkulu City HarsallakumAlQuranPesantren has given ease towards subordinate in doing evaluation towards the result 
of the work process that they are going through, making leadership effective, creating trust between leaders, and those being lead, as well as creating a pesantren and making it as one of the best pesantren in Bengkulu city.

The specific conclusion can be concluded by the following: (1) the determination of the leaders in pesantren have affected the creation of harmonic relationship between all pesantren's member. In this case it can be seen how the emotional bond that is created individually towards kiai that is always appreciating. The determination shown in every words uttered and by actions can be appreciated and the capacity as a kiai always makes him as a figure that is worthy of being followed or imitated in his environment, especially for the pesantren area. (2) The prestige to lead in pesantren creates subordinates realization that to accept the leadership to reach the goal that has been set. Prestige brings satisfaction for all members of the pesantren, because it always give recognition towards the achievement that the subordinates reached according to the norms that are applied, so that it creates joy for the subordinates. (3) The openness in leading Harsallakumpesantren has created trust between the leaders and those he leads. The trust is crucial in maintaining the continuity of the institution or organization like this pesantren, because the pesantren are build upon the trust and attitudes towards keeping the trust between all founder and all parties that have a role in building the pesantren. (4) Optimism in leading Bengkulu City HarsallakumAlQuranPesantren affects towards the beliefs that Usthad, Usthadzah, caretaker, santri, and the custodian santri in keeping the continuity of this pesantren. This is because there is a trust that if it is done well then the results obtained will be well, so that this pesantren can keep moving forward and grow.

\section{REFERENCES}

As Suwaidan Tharieq M dan Faisahal Umar Basyarahil.(2005).Melahirkan Pemimpin MasaDepan. Jakarta: Gema Insani.

Carnegie Dale , Sukses Pemimpin. (2015). Jakarta: Gramedia Pustaka.

Daulay, Haidar Putra. (2009).Sejarah Pertumbuhan Pembaruan Pendidikan Islam di Indonesia. Jakarta:

Kencana Prenada Media group.

Dimyati Hadam. (2014).Model Kepemimpinan dan Sistem Pengambilan Keputusan. Bandung: Pustaka Setia.

Deswary Dewi. (2014).Manajemen dan Kepemimpinan Pendidikan dalam Mewujudkan SDM Berkualitas Menuju Masyarakat ASEAN, Bunga Rampai 50 Tahun UNJ.

Goold Anne and Jannifer Evans. (1998).Relecting on School Managemen. Prancis: Falmer Press.

Himam Pathul. (2014).Kinerja Karyawan Berdasarkan Keterbukaan Terhadap Pengalaman, Organizational dan Budaya Organisasi, Jurnal Psikolgi, Fakultas Psikologi : Universitas Gadja Mada.

Jandaghi Gholamrezai. (2009).Hassan Zareei Matin and Ali Farjani, Comparing Transformational Leadreship In Successful an Unsuccessful Companies, (Teh Journal Of International Soscial Research, Volume 2/6 Winter.

Klann Gene. (2007).Building Character Strengthening the Herat of Good Leadership. San Francico: Jossey Bas.

Kouzes M. James dan Barry Z Posner. (1999).Tantangan Kepemimpinan. Batam: Interaksara.

Marhawati Basse. (2016).Urgensi Kepemimpinan Kepala Sekolah dalam Mencapai Kenerja Sekolah,Jurnal. Pascasarjana: Universitas Negeri Malang.

Muthahar Ahmad. (2002).Idiologi Pendidikan Pesantren Semarang: Pustaka Rizki Putra.

Nata Abudin. (2013).Kapita selekta Pendidikan Islam Jakarta: Raja Grafindo Perasada. .(1999) . Ilmu PendididikanTeoritis dan Praktis. Bandung: Remaja Rosdakarya. 
Purwanto Ngalim(2006).Administrrasi dan Supervisi Pendidikan, Cet XVI Bandung: Remaja Rosda Karya.

Rahayu Sari. (2015).Manajemen Pemberdyaan Sumber Daya Manusia di MAN Model Ciwaringin Cerebon, Jurnal Penelitian OASIS, Vol 8 No 02 Tahun 2015 , IAIN Syekh Nurjati: Cerebon.

Shelton Ken. (2002).Paradigma Baru Kepemimpinan. Jakarta: Elex Media Kumputindo.

Stephen P. Robbins. (2002).Manajamen. Jakarta: Indeks .(2005).Kepemimpinan Dalam Organisasi. Jakarta: Indeks.

Surya Muhammad.(2013).Psikologi Guru Konsep dan Aplikasi dari Guru untuk Guru. Bandung: Afabeta,

Yukl Gary. (1994).Leradership In Organization. New York: Pearson.

Yusuf Amirfaisal. (1995).Reorientasi Pendidikan Islam, Jakarta: Gema Insani Pres.

Wilkins David dan greg Carolin. (1976).Leadership Pure dan Simple. New York Chicago: McGraw Hill.

Zaleznek Abraham. (2008).Hedgehogs And Foxes Character, Leadership and Command In Organizations. New York: Palgrave Macmillan.

Zubaedi. (2011).Desain Pendidikan karakter Konsep dan Aplikasinya dalam Lembaga Pendidikan, Jakarta: Kencana. 